\title{
CZU:635.64:581.1 https://doi.org/10.53040/gppb7.2021.06 \\ ACTIVE EFFECTS OF LESS KNOWN BITUMINOUS ROCK ALGINITE ON THE BIOLOGICAL PROCESSES OF Solanum lycopersicum L.
}

\author{
Brindza Ján ${ }^{1}$, Horčinová Sedláčková Vladimíra ${ }^{1}$, Grygorieva Olga², Gryshko M.M. \\ ${ }^{1}$ Slovak University of Agriculture in Nitra, Institute of Biodiversity Conservation and Biosafety, Nitra, \\ Slovakia, e-mail: jan.brindza@uniag.sk, vladimira.sedlackova@uniag.sk \\ ${ }^{2}$ National Botanical Garden of the National Academy of Sciences of Ukraine, Kyiv, Ukraine \\ e-mail:olgrygorieva@gmail.com
}

\begin{abstract}
Applied two preparations of alginite formed from natural bituminous rock alginite in 4 different variants into the soil (granular forms) and spraying on leaves (extracts) in 2 cultivars of Solanum lycopersicum L. resulted in reduced production traits on plants and fruits, increased or decreased accumulation of macro and microelements content in plants and fruits and by increasing the antioxidant activity of the fruits compared to the control variant without alginite.

Key words: alginite, bituminous rock, preparations, Solanum lycopesricum, fruits, macro- and microelements, antioxidant activity

Introduction

Alginite, as an organic-bituminous rock, originates mainly from the bodies of dead algae (from the Latin algae). It formed as a rock during various geological periods, especially those that gave algae optimal conditions for growth and reproduction. Post-volcanic crater lakes or swamps were sites where alginite arising [18]. The first research and its practical use with bituminous rock in the Gerce region is in Hungary. Alginite from Hungary became the subject of follow-up research [14]. An economically important deposit of alginite was also located in Slovakia in Maar near Pinciná village northeast of the town of Lučenec [18]. The exploitation of alginite from the deposit is only in the beginning stage. Nevertheless, alginite has become an important research object even in the conditions of Slovakia at the Geocomplex research workplace $[12,9,10,5]$, University of Veterinary Medicine and Pharmaceuticals in Košice, [13, 16], Technical University of Zvolen [6,3], National Agriculture and Food Centre - Soil Science and Conservation Research Institute [2]; State Geological Institute of Dionýz Štúr [1]. Natural and modified alginite has unique effects on plants, animal organisms, soil, water and solving other current environmental problems [5].
\end{abstract}

\section{Materials and methods}

Object of the experiment - cultivar of tomato Denár (D) - late ripening of fruits, high yield of juice, used for manual and mechanized fruit picking, Odeon $(\mathrm{O})$ - semi-early cultivar suitable for ketchup preparation.

Experimental location - Slovakia, Nitra; Evaluated parts of plants - plants, fruits.

Tested innovated alginite products in following variants: V1 - C (COO and COD) - control variant without alginate; V2 (KV1O1 - 3, and PV1D1 - 3) curative treatment with $0.2 \%$ AUZ solution (ultrasound-treated alginite); V3 (PK201-3, and PK2D1-3) preventive treatment with 04\% AUZ solution (alginite treated with ultrasound); V4 (PV3O1-3 and PV3D1-3) AUZ powder treatment (ultrasonic treated alginite); V5 (PK4O1-3 and PK4D1-3) treated with ALGEX 4 (30ml.1 $\left.{ }^{-1}\right)$; Application of alginite preparations - curative (K) during plant vegetation.

Determination of macro and microelement content - AAS-AMA Atomic absorption spectrometry. Determination of antioxidant analysis of fruits - DPPH method (Brand-Williams et al., 1995).

\section{Results and discussions}

The application of alginite preparations to tomatoes in all variants (V2-V4) resulted in a reduction in plant weight as well as a reduction in the average fruit weight compared to the control variant (Table 1). This effect can be considered both negative and positive. 
Table 1. Comparison of applied preparations of alginite in the form of variants on plant weight and fruit weight of the cultivars Solanum lycopersicum L. LSD test, $\alpha-0,05$

\begin{tabular}{|c|c|c|c|c|c|c|c|c|c|}
\hline Variants & Weight of plant $(\mathbf{g})$ & $\mathbf{1}$ & $\mathbf{2}$ & $\mathbf{3}$ & Variants & Weight of fruit (g) & $\mathbf{1}$ & $\mathbf{2}$ & $\mathbf{3}$ \\
\hline V5 & 2236.942 & $* * * *$ & & & $\mathbf{V 2}$ & 61.633 & $* * *$ & & \\
\hline V2 & 2624.657 & $* * * *$ & $* * * *$ & & V3 & 63.365 & $* * * *$ & & \\
\hline V4 & 2688.788 & $* * * *$ & $* * * *$ & & V5 & 68.533 & & $* * * *$ & \\
\hline V3 & 2896.000 & & $* * * *$ & & V4 & 68.830 & & $* * * *$ & \\
\hline V1 & 4618.813 & & & $* * * *$ & V1 & 73.000 & & & $* * * *$ \\
\hline
\end{tabular}

Table 2. Comparison of the determined lowest and highest contents of tested macro- and microelements in the dry matter of parts of plants of the cultivar Denar of Solanum lycopesricum

\begin{tabular}{|c|c|c|c|c|c|}
\hline \multicolumn{6}{|c|}{ Dry matter of stems } \\
\hline \multicolumn{6}{|c|}{ a) The lowest values of the content of evaluated macro and microelements were determined for the variants } \\
\hline KOD (5) & KV1D (4) & KV2D (1) & KV3D (4) & KV4D(3) & KV5D (3) \\
\hline P-Al-Cu-Sn-Zn & K-Hg-Cr-Ni & $\mathrm{Se}$ & Ca-Na-S-Mn & $\mathrm{Co}-\mathrm{Fe}-\mathrm{Sb}$ & $\mathrm{Mg}-\mathrm{Si}-\mathrm{N}$ \\
\hline \multicolumn{6}{|c|}{ b) The highest values of the content of evaluated macro and microelements were determined for the variants } \\
\hline KOD (3) & KV1D (1) & KV2D (11) & KV3D (2) & KV4D(2) & KV5D(2) \\
\hline Na-K-Co & Se & $\begin{array}{c}\text { Ca-Mg-S-P-Al-Cu-Fe- } \\
\text { Mn-Cr-Ni-N }\end{array}$ & $\mathrm{Hg}-\mathrm{Si}$ & $\mathrm{Hg}-\mathrm{Zn}$ & $\mathrm{Sb}-\mathrm{Sn}$ \\
\hline \multicolumn{6}{|c|}{ Dry matter of leaves } \\
\hline \multicolumn{6}{|c|}{ a) The lowest values of the content of evaluated macro and microelements were determined for the variants } \\
\hline KOD (2) & KV1D & KV2D & KV3D (3) & KV4D (5) & KV5D (11) \\
\hline $\mathrm{S}-\mathrm{Cu}$ & - & - & Ca-Mg-N & $\mathrm{Na}-\mathrm{K}-\mathrm{Se}-\mathrm{Zn}-\mathrm{Pb}$ & $\begin{array}{l}\text { P-Al-Co-Fe-Hg-Li- } \\
\text { Mn-Sc-Si-Cr-Ni }\end{array}$ \\
\hline \multicolumn{6}{|c|}{ b) The highest values of the content of evaluated macro and microelements were determined for the variants } \\
\hline KOD (1) & KV1D (14) & KV2D (1) & KV3D & KV4D (3) & KV5D (2) \\
\hline $\mathrm{Hg}$ & $\begin{array}{c}\text { Mg-Na-P-Al-Co-Cu-Fe-Li- } \\
\text { Mn-Zn-Sc-Cr-Ni-Pb }\end{array}$ & $\mathrm{Si}$ & - & $\mathrm{Ca}-\mathrm{S}-\mathrm{Se}$ & $\mathrm{K}-\mathrm{N}$ \\
\hline \multicolumn{6}{|c|}{ Dry matter of fruits } \\
\hline \multicolumn{6}{|c|}{ a) The lowest values of the content of evaluated macro and microelements were determined for the variants } \\
\hline KOD (4) & KV1D $(6)$ & KV2D (1) & KV3D & KV4D(2) & KV5D (4) \\
\hline $\mathrm{Cu}-\mathrm{Mn}-\mathrm{Sn}-\mathrm{Zn}$ & Mg-Na-K-S-P-N & $\mathrm{N}$ & - & $\mathrm{Al}-\mathrm{Si}$ & $\mathrm{Ca}-\mathrm{Fe}-\mathrm{Sn}-\mathrm{Ni}$ \\
\hline \multicolumn{6}{|c|}{ b) The highest values of the content of evaluated macro and microelements were determined for the variants } \\
\hline KOD (1) & KV1D (2) & KV2D (3) & KV3D (2) & KV4D (1) & KV5D (6) \\
\hline $\mathrm{Si}$ & Ca-Sn & Al-Zn-Ni & $\mathrm{Fe}-\mathrm{N}$ & $\mathrm{P}$ & $\mathrm{Mg}-\mathrm{Na}-\mathrm{K}-\mathrm{S}-\mathrm{Cu}-\mathrm{Mn}$ \\
\hline
\end{tabular}

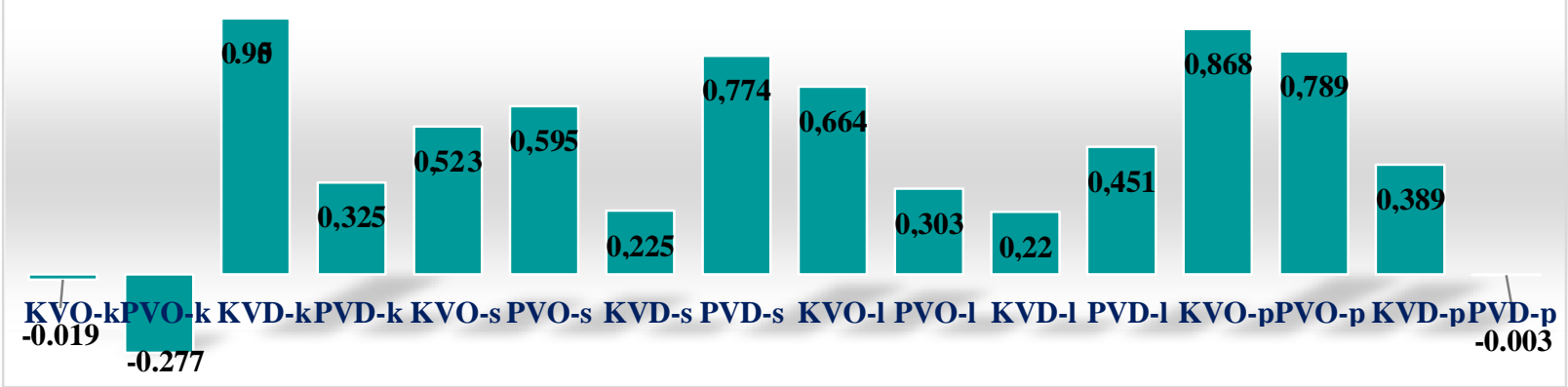

Figure 1. Comparison of dependences between aluminium and chromium content expressed by correlation coefficients according to Pearson's correlation analysis of innovated alginite products in individual plant parts of tested cultivars Odeon and Denár within evaluated variants.

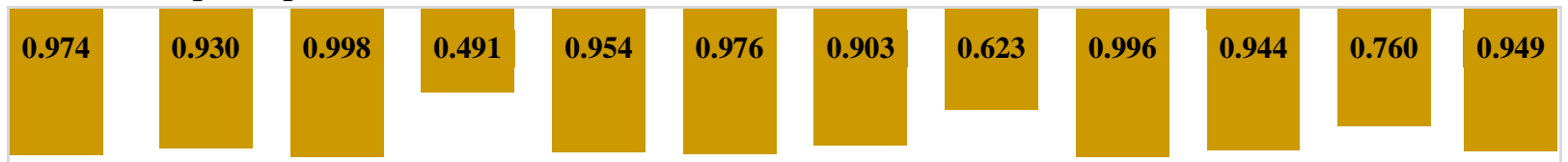

Figure 2. Comparison of dependences between silicon and aluminium content expressed by correlation coefficients according to Pearson's correlation analysis of innovated alginite products in individual plant parts of tested cultivars Odeon and Denár within evaluated variants. 


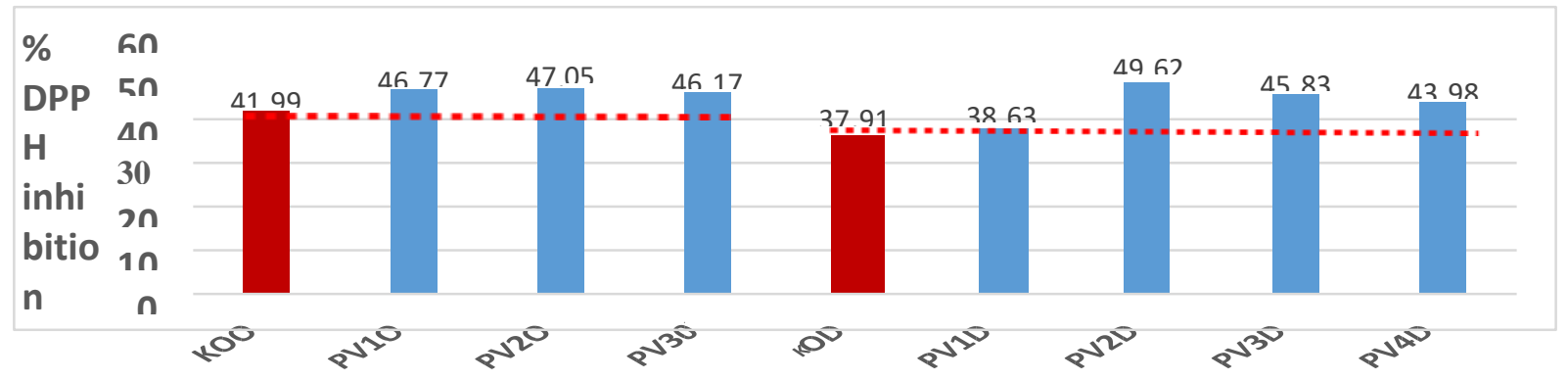

Figure 3. Antioxidant activity of preventively (P) treated fruits of tomato cultivars Odeon and Denar in aqueous extract after application of various developed alginite products (PV1 - PV4).

\begin{tabular}{|c|c|c|}
\hline $\begin{array}{c}\text { Improves seed germination, plant } \\
\text { growth and development } \\
\text { Kovár et al.,2021;Tužinský et al., 2015 }\end{array}$ & $\begin{array}{c}\text { Stabilization of probi- } \\
\text { otic preparations } \\
\text { Styková et al., 2016 }\end{array}$ & $\begin{array}{c}\text { Increases the yield and pro- } \\
\text { duction of plant parts } \\
\text { Kádár et al., 2015 }\end{array}$ \\
\hline $\begin{array}{c}\text { It allows the retention of water in } \\
\text { the soil and the gradual supply of } \\
\text { water to plants }\end{array}$ & $\begin{array}{c}\text { It degrades the decomposi- } \\
\text { tion of pesticide and drug } \\
\text { residues in water } \\
\text { Bublinec and Gregor, } 1997\end{array}$ & $\begin{array}{c}\text { Guhl et al., 2018; Kropp et al., } \\
2021\end{array}$ \\
\hline $\begin{array}{c}\text { Improves fertility and microbiologi- } \\
\text { cal properties of soils } \\
\text { Gömöryová et al., 2009 }\end{array}$ & $\begin{array}{c}\text { Retains nutrients in } \\
\text { the soil }\end{array}$ & $\begin{array}{c}\text { Stabilizes microorganisms } \\
\text { in animal organisms } \\
\text { Strompfová et al., 2018 }\end{array}$ \\
\hline
\end{tabular}

Figure 4. Summary of some determined effects after application of natural or modified alginite according to the literary data.

The results of the experiment showed that the application of alginite preparations significantly and specifically affected the accumulation of macro- and microelements in the roots, stems, leaves and fruits (Table 2). Compared to the control variant (V1), the accumulation of the content of some macro- and microelements was significantly reduced, and in some cases increased.

By evaluating the correlation dependence between the content of tested macro-and microelements in tomato plants, we also determined significant differences. The results indicate a very interesting correlation between the silicon and aluminium content (Figure 2) and the aluminium and chromium content (Figure 1). We do not provide further results.

The application of alginite preparations was proved by an increase in antioxidant activity in aqueous extracts, which is also documented in the presentation in Figure 3.

The reduction in biomass production is significant with a reduction in nutrient depletion from the soil. The formation of lower weight fruits results in an improvement in their quality (Figure 3).

The knowledge obtained from the experiment contributes and complements the knowledge of other authors about the significant effects on the production and quality of plants, the improvement of water, soil and the solution of many other current problems.

\section{Conclusions}

By applying the formed preparations from natural bituminous rock alginite to tomato plants, the effects on reducing the weight of plants and fruits were confirmed in experiments. Other effects were manifested by a significant change in the accumulation of macro and microelements in the roots, stems, leaves and fruits. Application with alginite resulted in an increase in the antioxidant activity of the fruit. It is very difficult to justify the determined effects of the application of alginite to tomato in this experiment as well as many other significant effects determined by other authors on other plant species and in other areas.

It is very likely that these effects of alginite are manifested due to its content of more than 70 macro and microelements in its composition. A positive component of alginite is also the favourable content of humates. A priority feature of natural alginite is also the high binding of water, which plants can grad- 
ually take in dry conditions. The least knowledge is about the content and composition of the organic component alginite, which requires many further experiments.

\section{Acknowledgments}

The scientific work was processed within the solution of contract research of the organic mineral alginite with the financial support and consent of GEOCOMPLEX, a.s. company. The results of this research are the asset of GEOCOMPLEX, a.s. company.

\section{Bibliography}

1. BALÁŽ, P., STUPÁK, J., CICMANOVÁ, S., KOBULSKÝ, J., HALMO, J. 2010. Analýza palivovoenergetických surovín a možnosti využívania zásob a prognóznych zdrojov z pohl'adu ich ekonomickej efektívnosti, regionálny geologický výskum [Analysis of fuel and energy raw materials and the possibility of using reserves and forecast resources in terms of their economic efficiency, regional geological research]. In Záverečná správa, archív ŠGÚDŠ, Bratislava, 216 p.

2. BARANČ́ÍKOVÁ, G., KLUČÁKOVÁ, M., MADARAS, M., MAKOVNÍKOVÁ, M., PEKAŘ, M. 2003. Comparison of chemical structure of humic acids isolated from various soil types and alignite. In Humic Substances in the Environment, vol. 1/2, p. 3-8.

3. BELÁČEK, B. 2006. Možnosti využitia novej nerastnej suroviny - alginitu v lesnom hospodárstve. [Possibilities of using a new mineral - alginite in forestry]. Dizertačná práca, Manuskript : KPP TU vo Zvolene, Zvolen, 139 p.

4. BRAND-WILLIAMS, W., CUVELIER, M. E., BERSET, C. 1995. Use of a free radical method to evaluate antioxidant activities. In Lebensmittel Wissenschaft und Technologie, vol. 28 (1), p. 25-30. https://doi.org/10.1016/S0023-6438(95)80008-5

5. BRINDZA, J., VOZÁR, L., MIKO, M., GAŽO, J., KOVÁR, P., HORČINOVÁ SEDLÁČKOVÁ, V., GRYGORIEVA, O. 2021. Unique effects of alginite as a bituminous rock on soli, water, plants and animal organisms. Agrobiodivers Improv Nutr Helath Life Qual, 5 (1), p. 169-184. https://doi.org/10.15414/ainhlq.2021.0016

6. BUBLINEC, E., GREGOR, J. 1997. Význam alginitu pre vododržnost' pôdy a zásobovanie rastlín vodou [Importance of alginite for soil water retention and plant water supply]. Zvolen, Lesnícka fakulta TU vo Zvolene, Ústav ekológie lesa SAV vo Zvolene: 4.

7. GÖMÖRYOVÁ, E., VASS, D., PICHLER, V., GÖMÖRY, D. 2009. Effect of alginite amendment on microbial activity and soil water content in forest soils. In Biologia, vol. 64, p. 585-588. https://doi.org/10.2478/s11756-009-0081-z

8. GUHL, A., TRÖBS, R., BERTAU, M. 2018. Alginite - a naturebased solution for emerging-contaminant-polluted water. Project: Wastewater treatment using alginite from Gercé, Hungary. In Conference: The 28th Annual International Conference on Soil, Water, Energy, and Air, March 2018, Hungary.

9. HORČINOVÁ SEDLÁČKOVÁ, V., ŠIMKOVÁ, J., MŇAHONČ́KOVÁ, E., HRÚZOVÁ, M., KOVÁR, P. VOZÁR, L., HRIC, P. 2021. Effect of alginite in the form of ALGEXr 6 preparation on the biomass formation and antioxidant activity of some medicinal plants. Agrobiodivers Improv Nutr Helath Life Qual, 5 (1), p. 80 94. https://doi.org/10.15414/ainhlq.2021.0009

10. KOVÂR, P., VOZÁR, L., HRIC, P., BRINDZA, J., VEREŠOVÁ, P. 2021. Influence of alginite and extracts from it on germination of Kentucky bluegrass (Poa pratensis L.). In Proceedings: XV. národní odborný a vedecký seminár "Osivo a sadba", February 4th, p. 137-142. ISBN 978-80-213-3080-1.

11. KROPP, A.-C., UNZ, S., BECKMANN, M., SCHMIDT, A., GUHL, A.C., BERTAU, M., KNOBLICH, A., HEIDE, G. 2021. Regeneration potential of alginite for the depletion of organic contaminants from wastewater, In Chemie Ingenieur Technik, vol. 93 (3), p. 447-455. https://doi.org/10.1002/cite.202000099

12. KULICH, J., VALKO, J., OBERNAUER, D. 2001. Perspective of exploitation of alginit in plant nutrition. In Journal of Central European Agriculture, vol. 2, p. 3-4.

13. NEMCOVÁ, R., MAĎAR, M., SLÍŽOVÁ, M., CZERWINSKI, J., HRČKOVÁ, G., et al. 2012-2015. Využitie alginitu na stabilizáciu účinku probiotických bioprípravkov v medicíne a zdravej výžive [Use of alginite to stabilize and stimulate the effect of probiotic bio preparations in medicine and dietetics]. In $Z a ́$ verečná správa projektu: APVV-0199-11.

14. SOLTI, G. 1987. Az Alginit [The alginite]. Budapest : A Magyar Állami Földtani Intézet Alkalmi Kiadványa, 40 p.

15. STROMPFOVÁ, V., KUBAŠOVÁ, I., FARBÁKOVÁ, J., MAĎARI, A., GANCARČ́́KOVÁ, S., MUDRONOVÁ, D., LAUKOVÁ, A. 2018. Evaluation of probiotic Lactobacillus fermentum CCM 7421 administration with alginite in dogs. In Probiotics \& Antimicrocrobial Proteins, vol. 10, p. 577-588. https://doi.org/10.1007/s12602-017-9370-y

16. STYKOVÁ, E., NEMCOVÁ, R., VALOCKYY, I. 2016. Probiotický prípravok stabilizovaný na alginite [Probiotic preparation stabilised on alginite]. Transfer technológií na Slovensku a v zahraniči : Zborník abstraktov z konferencie s medzinárodnou účast'ou, Bratislava, p. 65-66.

17. TUŽINSKÝ. M., KUPKA, I., PODRÁZSKÝ, V., PRKNOVÁ, H. 2015. Influence of the mineral rock alginite on survival rate and re-growth of selected tree species on agricultural land. In Journal of Forest Science, vol. 61 (9), p. 399-405. https://doi.org/10.17221/11/2015-JFS

18. VASS, D., KONEČNÝ, V., ELEČKO, M., MILIČKA, J., SNOPKOVÁ, P., ŠUCHA, V., KOZAČ, J., SKKRABANA, R. 1997. Alginite - new source of Slovak nonmetalliferous raw materials (Pinciná deposit). In Mineralica Slovaca, vol. 29 (1), p. 1-39. 